\title{
Evaluation of Environmental Flows in Dalfard River Using Hydrological Methods
}

\author{
Hedieh Ahmadpari ${ }^{1}$, Behnam Rigi Ladez ${ }^{2}$, Elham sadat Shokoohi ${ }^{3}$, Milad kheiry Ghojeh Biglou ${ }^{4 *}$ \\ ${ }^{1}$ M.Sc. Graduate of Irrigation and Drainage, University of Tehran, Iran \\ h.ahmadpari@gmail.com \\ ${ }^{2}$ M.Sc. Student of Irrigation and Drainage, University of Zabol, Iran \\ behnam.rigi@gmail.com \\ ${ }^{3}$ M.Sc. Graduate of Desert Area Management, University of Tehran, Iran \\ elshokoohi13@gmail.com \\ ${ }^{4}$ M.Sc. Graduate of Water and Hydraulic Structures, Department of Civil Engineering, \\ Parsabad Moghan Branch, Islamic Azad University, Parsabad Moghan, Iran \\ (Corresponding Author: eng.miladenoor@gmail.com)
}

\begin{abstract}
On the one hand, Iran suffers from limited freshwater resources and, on the other hand, faces increasing demand for water for various uses, which has led to dam construction, especially over the past three decades in Iran. Today, increasing awareness of the effects of water resources development plans on rivers and their dependent ecosystems has led to the estimation of environmental water requirement as one of the essential parts of water resource planning studies in dams. The main objective of this study was to estimate environmental flow in Dalfard River by using Tennant, Tessman, Average Base Flow (ABF) and Flow Duration Curve (FDC) Shifting methods and compare the results methods with each other. The results showed that Tennant method consider $30 \%$ mean annual flows for spring and summer, $10 \%$ mean annual flows for autumn and winter, 0.24 and 0.08 CMS, respectively. Methods Tessman and ABF, estimate, 0.37 and $0.10 \mathrm{CMS}$, respectively. According to results, the amounts generated from FDC Shifting method are more proper because of considering the ecological management qualification. Therefore, 0.334 CMS (equals to $42.8 \%$ of mean annually flow) was obtained as average environmental requirement of Dalfard River in ecological management class C (maintains minimum ecological term in river). Also moderated class $C$ has good match with regime of flow at several months and is acceptable in area in terms of managerial, agricultural uses, drinking and etc. The suggested method in this research is not the ultimate solution for environmental problems of Dalfard River. Lack of comprehensive required ecological information at river's ecosystem studies, cause to estimating eco-hydrology by less coefficient of confidence.
\end{abstract}

Keywords: Environmental water requirement, Tennant, Tessman, Average Base Flow, FDC Shifting

\section{1-Introduction}

Rivers have a significant impact on human life as its pollution and harming leads to the degradation of the aquatic ecosystem and eventually will cause irreparable and irreversible damage. In order to protect the stability of ecosystems in the rivers, a criterion named "environmental stream" or "environmental water requirement" is defined for the rivers which actually expresses how much current is required to maintain an aquatic ecosystem. Several methods are available for estimating this flow, however, the International Institute of Water Management Resources has classified these methods into five groups. These consist of Hydrological Methods, Hydraulic Methods, Habitat Simulation Methods, Comprehensive Methods and Combinational Methods (Panahi et al., 2016). Hydrological index methods are the simplest type of environmental flow assessment which depends on the use of historical hydrological data for making flow recommendations. These data are usually in the form of long-term, historical monthly or daily discharge records. Because of the dependence on past flow data, these methods are also named Historical Flow (Gopal, 2013). Estimating instream flows, hydrological index methodologies are the simplest and least data intense methods (Shahriari Nia et al., 2015). The method involves an expert assessment, based on the available knowledge of hydrology, river characteristics and some fish species of primary interests, and of level of flow that would maintain the stream/river ecosystem at an acceptable or desired level. Hydrological methods assume a relationship between flow and biological parameters (Gopal, 2013). Hydrological methods were the first to be developed and still continue to be developed further and used widely. About $30 \%$ of all methods belong to this category, make relatively little use of morphological and biological information on rivers and are usually region-specific (Shahriari Nia et al., 2015). Mostafavi and Yasi (2015) evaluated the environmental flows in Barandozchi River-Urmia Lake Basin with five hydrological methods (1-Tennant, 2-Tessman, 3-Flow Duration Indices, 4-FDC shifting, 5-DRM). The results indicated that the flow allocation for the river environment ( $4 \%$ of mean annual flows) is not sufficient to meet the minimum flow requirements for any of the targeting species in the river ecosystem. In order to maintain the Barandozchi River at minimum acceptable environmental status (i.e. Class $\mathrm{C}$ of environmental 
management), an average annual flow of $1.9 \mathrm{~m} 3 / \mathrm{s}(26 \%$ MAR) are to be provided. The distribution of monthly flow rates in the river is also recommended for sustaining the Barandozchi River life. Abdi et al. (2014) evaluated the environmental requirement in Zarrinehrood River (located in North West of Iran) by four hydrological methods (Tennant, Tessman, Desktop Reserve Model (DRM) and FDC Shifting). According to results, the amounts generated from FDC Shifting method are more proper because of considering the ecological management qualification. Therefore, $16.7 \mathrm{CMS}$ (equals to $33 \%$ of mean annually flow) was obtained as average environmental requirement of Zarrinehrood river in ecological management class $\mathrm{C}$ (maintains minimum ecological term in river). The critical period for the river is during August to October. In this period, the monthly flow of $12.6,11.6$ and $6.3 \mathrm{~m}^{3} \mathrm{~s}^{-1}$, are required to flow downstream in order to preserve the river life. Behmanesh et al. (2017) evaluated the environmental flow in Khorkhorehchay River two methods of FDC shifting and DRM. Regarding river classification to various environmental management classes, since class $C$ is ecologically favorable, it has been selected as the optimal managerial class in this research. Given that the DRM method requires quantitative data in calculations, in addition to the hydrological conditions, it also considers the ecological conditions; therefore, it is recommended that the DRM in class C is considered as the minimum environmental flow. Also, the results of the research showed that to maintain the Khorkhorehchay River at minimum acceptable environmental situations (i.e. Class $\mathrm{C}$ of environmental management), an average annual flow of $2.05 \mathrm{~m} 3 / \mathrm{s}(23 \%$ mean annual flow) is to be provided along the river to Urmia lake. The main purpose of this research is to estimate the environmental flow of the Dalfard River using methods Average base flow, Tennant, Tessman and FDC Shifting.

\section{2-1-River of study}

\section{2-Materials and methods}

Dalfard River, a permanent river with a length of $30 \mathrm{~km}$. The river originated from Bahr-Aseman Mountain in the 53 kilometers northwest of Jiroft (In Kerman Province, Iran). The river is located in the geographical coordinates of East of $57^{\circ} 36^{\prime}$ and $29^{\circ} 1^{\prime}$ North. Figure 1 shows the position of the Dalfard River in country of Iran. Koldan hydrometric station data was used to calculate the environmental discharge of the Dalfard River.

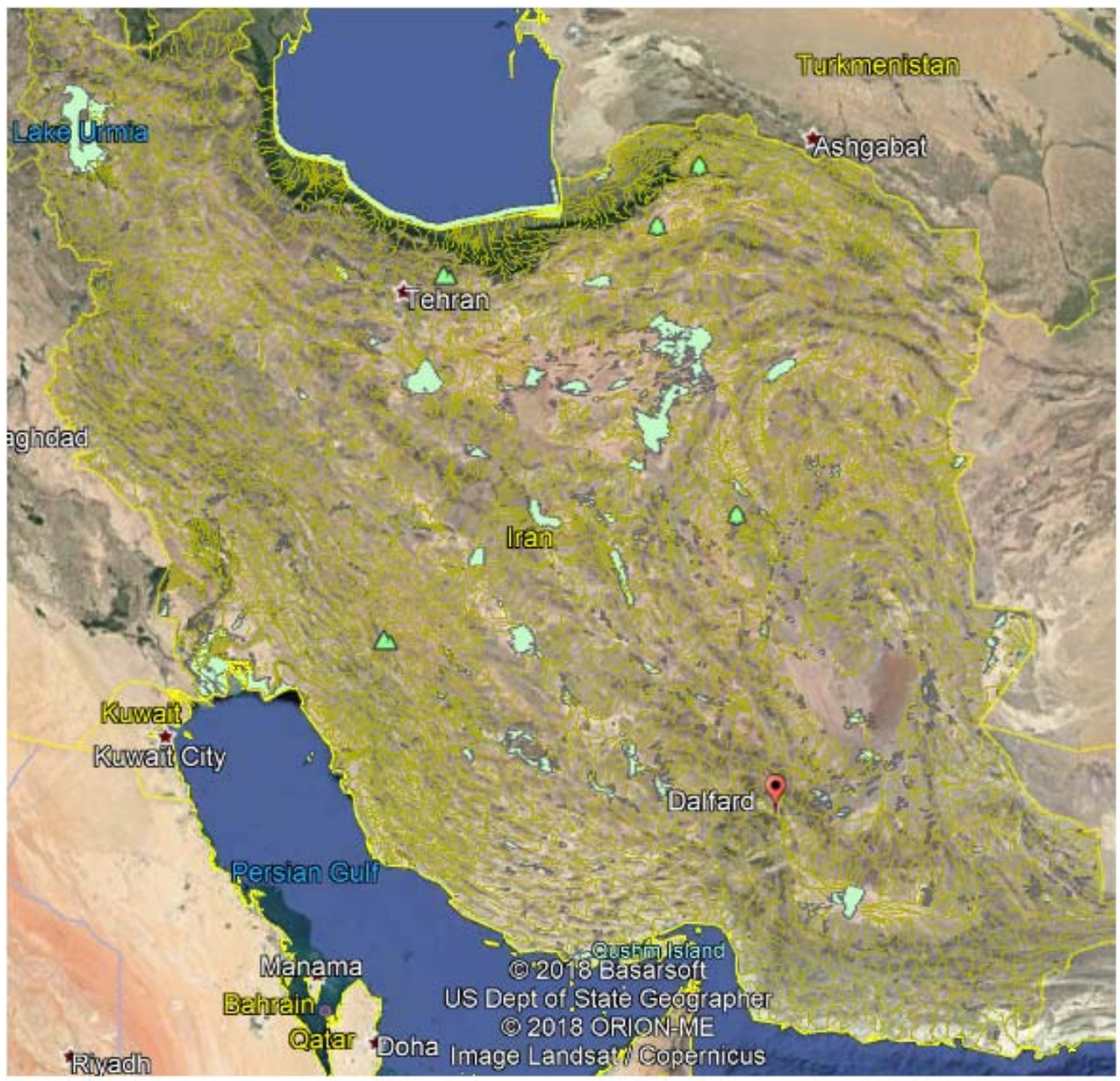

Figure 1-Location of the study area in Iran 


\section{2-2-Average Base Flow (ABF) method}

In this method, using the minimum average monthly flow of the river, the environmental water requirement is determined. Thus, at least the river discharge is determined in the long term as the water requirement and this amount of water has to be continuously flowing in the river throughout the year. In fact, this method does not consider the variability that is essential for ecosystem health by determining the minimum monthly discharge of the river and applying it as an environmental need for the river for all months of the year (mirakhorli et al, 2012).

\section{2-3-Tenant Method (Montana Method)}

The Tennant (or Montana) method developed by Tennant (1976) is the most common hydrological method applied worldwide and has been used by at least 25 countries (Karimi et al., 2012). This method is based on empirical relationships between the specified percent of the MAR and the prescribed ecological condition of the river. The Tennant method uses a percentage of the MAR for two different 6-month periods to define conditions of flow related to fishery, wildlife, recreational, and environmental resources (Table 1).

Table 1-The Tennant (Montana) method (1976)

\begin{tabular}{ccc}
\hline Description of flows & \multicolumn{2}{c}{ Recommended base flow regimens (percent of mean annual runoff) } \\
\cline { 2 - 3 } & October-March & April-September \\
\hline Flushing or maximum & 200 & 200 \\
Optimum range & $60-100$ & $60-100$ \\
Outstanding & 40 & 60 \\
Excellent & 30 & 50 \\
Good & 20 & 40 \\
Fair or degrading & 10 & 30 \\
Poor or minimum & 10 & 10 \\
Severe degradation & $<10$ & $<10$ \\
\hline
\end{tabular}

\section{2-4-Tessman Method}

The Tessman method is a modification of the Tennant method, both of which are based on an analysis of long term stream gauge records. The method has been suggested by Dunbar his colleagues in Canada and has a widespread application in this country (Tharme, 2003). The basic data for these methods are the long-term mean annual (MAF) and mean monthly flow (MMF) records for the watercourse being studied, augmented by limited field measurements and photographs taken at multiple discharges (Maunder \& Hindley, 2005). The Tessman rule recommends minimum flow guidelines as follows (Gopal, 2013):

1) $\mathrm{MMF}$, if $\mathrm{MMF}<40 \% \mathrm{MAF}$;

2) $40 \%$ of MAF, if $40 \% \mathrm{MAF}<\mathrm{MMF}<100 \% \mathrm{MAF}$; and,

3) $40 \%$ of MMF, if MMF $>$ MAF.

The Tessman rule has been applied in Manitoba, Canada for use in perennial streams (Shahriari Nia et al., 2015). This method provides a "good-condition" of Tennant method. To examine the hydrologic condition of a river, the monthly assessment of water is considered by Tessman method. This method has been applied as a model of the evaluating the environmental flow but it is not proper to use in arid and semi-arid regions as it caused very low or high flows that may affect in rivers' destruction (Shahriari Nia et al., 2015).

\section{2-5- Flow Duration Curve (FDC) Shifting method}

The FDC shifting method is a new hydrological method developed by Smakhtin and Anputhas (2006). The method uses monthly flow data and is built around a period-of-record FDC. This method includes 4 subsequent steps to evaluate environmental flow (EF), as follows:

Step 1: Simulating reference hydrological conditions. The first step is the calculation of a representative FDC for a desired river reach using a monthly time series. All FDCs in this method are represented by a table of flows corresponding to 17 fixed percentage points: $0.01,0.1,1,5,10,20,30,40,50,60,70,80,90,95,99,99.9$, and $99.99 \%$ (Shaeri Karimi et al., 2012).

Step 2: Defining environmental management classes (EMCs). Razzaghi Rezaeieh et al. (2019) Presented the environmental management classes in Table 2. The purpose of determining EF is to maintain or upgrade an ecosystem to some prescribed or negotiated condition, also referred to as desired future state, EMC, ecological management category, and level of environmental protection. Higher EMCs require a higher allocation of water for ecosystem maintenance or conservation and a higher preservation of flow variability. Six EMCs are used in this method and set of the EMCs are similar to those described in DWAF (1999). 
Step 3: Establishing environmental FDCs from reference condition. A simple approach is used to determine the default FDC representing a summary of EF for each EMC. These curves are determined by the lateral shift of the original reference FDC to the left, along the probability axis. Details of this procedure are presented by Smakhtin and Anputhas (2006).

Step 4: Simulating continuous monthly time series of EFs. An environmental FDC for any EMC gives only a summary of the EF regime acceptable for this EMC. However, once such a curve is determined, as described above, it may also be converted into an actual environmental monthly flow time series. The spatial interpolation procedure described in detail by Hughes and Smakhtin (1996) can be used for this purpose. Generation of the EF time series completes the desktop EF estimation for a site.

Mean annual environmental runoff (MAER) using an EF time series is calculated in the same manner as mean annual runoff (MAR) using the original time series. Dividing the first value by the second value (MAER/MAR) gives the percentage of MAR in each EMC (Shaeri Karimi et al., 2012). Global Environmental Flow Calculator (GEFC) is a free software package developed by the International Water Management Institute (IWMI), Sri Lanka, in collaboration with the Water Systems Analysis Group of the University of New Hampshire, for desktop assessments of EFRs in river basins. It is coded in Visual Basic 2005 and uses the FDC shifting technique to estimate EF (Smakhtin and Eriyagama, 2008). In this study, GEFC (Version 1.0) was used to analyze the data and estimate EFR.

Table 2-Environmental management classes (EMC) (Razzaghi Rezaeieh et al, 2019).

\begin{tabular}{|c|c|c|}
\hline EMC & Ecology definition & management perspective \\
\hline A (natural) & $\begin{array}{l}\text { Natural rivers with minor modification } \\
\text { of instream and riparian habitat }\end{array}$ & $\begin{array}{l}\text { Protected rivers and basins; reserves and } \\
\text { national parks; no new water projects } \\
\text { (dams, diversions) allowed }\end{array}$ \\
\hline B (slightly modified) & $\begin{array}{l}\text { Slightly modified and/or ecologically } \\
\text { important rivers with largely intact } \\
\text { biodiversity and habitats despite water } \\
\text { resources development and/or basin } \\
\text { modifications }\end{array}$ & $\begin{array}{l}\text { Water supply schemes or irrigation } \\
\text { development present and/ or allowed }\end{array}$ \\
\hline C (moderately modified) & $\begin{array}{l}\text { The habitats and dynamics of the biota } \\
\text { have been disturbed, but basic } \\
\text { ecosystem functions are still intact; } \\
\text { some sensitive species are lost and/or } \\
\text { reduced in extent; alien species present }\end{array}$ & $\begin{array}{l}\text { Multiple disturbances (e.g., dams, } \\
\text { diversions, habitat modification and } \\
\text { reduced water quality) associated with } \\
\text { the need for socioeconomic development }\end{array}$ \\
\hline D (largely modified) & $\begin{array}{l}\text { Large changes in natural habitat, biota } \\
\text { and basic ecosystem functions have } \\
\text { occurred; species richness is clearly } \\
\text { lower than expected; much lowered } \\
\text { presence of intolerant species; alien } \\
\text { species prevail }\end{array}$ & $\begin{array}{l}\text { Significant and clearly visible } \\
\text { disturbances (including dams, diversions, } \\
\text { transfers, habitat modification and water } \\
\text { quality degradation) associated with } \\
\text { basin and water resources development }\end{array}$ \\
\hline E (seriously modified) & $\begin{array}{l}\text { Habitat diversity and availability have } \\
\text { declined; species richness is strikingly } \\
\text { lower than expected; only tolerant } \\
\text { species remain; indigenous species can } \\
\text { no longer breed; alien species have } \\
\text { invaded the ecosystem }\end{array}$ & $\begin{array}{l}\text { High human population density and } \\
\text { extensive water resources exploitation; } \\
\text { generally, this status should not be } \\
\text { acceptable as a management goal; } \\
\text { management interventions are necessary } \\
\text { to restore flow pattern and to "move"' a } \\
\text { river to a higher management category }\end{array}$ \\
\hline F (Critically modified) & $\begin{array}{l}\text { Modifications have reached a critical } \\
\text { level; ecosystem has been completely } \\
\text { modified with almost total loss of } \\
\text { natural habitat and biota; in the worst } \\
\text { case, basic ecosystem functions have } \\
\text { been destroyed and changes are } \\
\text { irreversible }\end{array}$ & $\begin{array}{l}\text { This status is not acceptable from the } \\
\text { management perspective; management } \\
\text { interventions are necessary to restore } \\
\text { flow pattern and river habitats (if still } \\
\text { possible/feasible) to "move" a river to a } \\
\text { higher management category }\end{array}$ \\
\hline
\end{tabular}




\section{3-Results and discussion}

In this section, the environmental water requirement of the Dalfard River is calculated from the four methods of average base flow (ABF), Tennant, Tessman and FDC Shifting, and finally compared.

\section{3-1-Hydrological information}

The Mean Annual Runoff (MAR) of the Dalfard River for the 32-year period (1987-2018) is 24.41 million cubic meters (MCM). Figures 2 and 3 show the annual time series and monthly distribution for the data of Koldan hydrometric station in the 32 -year period. Figure 4 shows the flow duration curve for the Dalfard River. The average flow in different months of the year with the statistical period (1987-2018) is presented in Table 3.

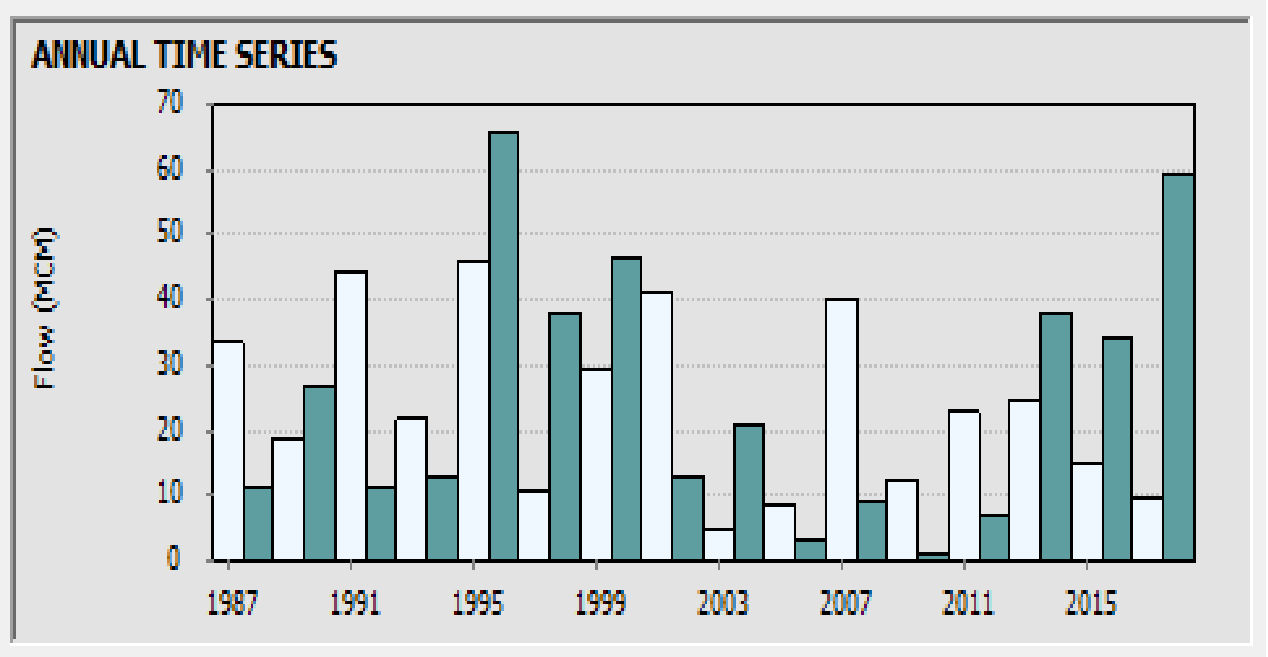

Figure 2-The annual time series of the Dalfard River discharge

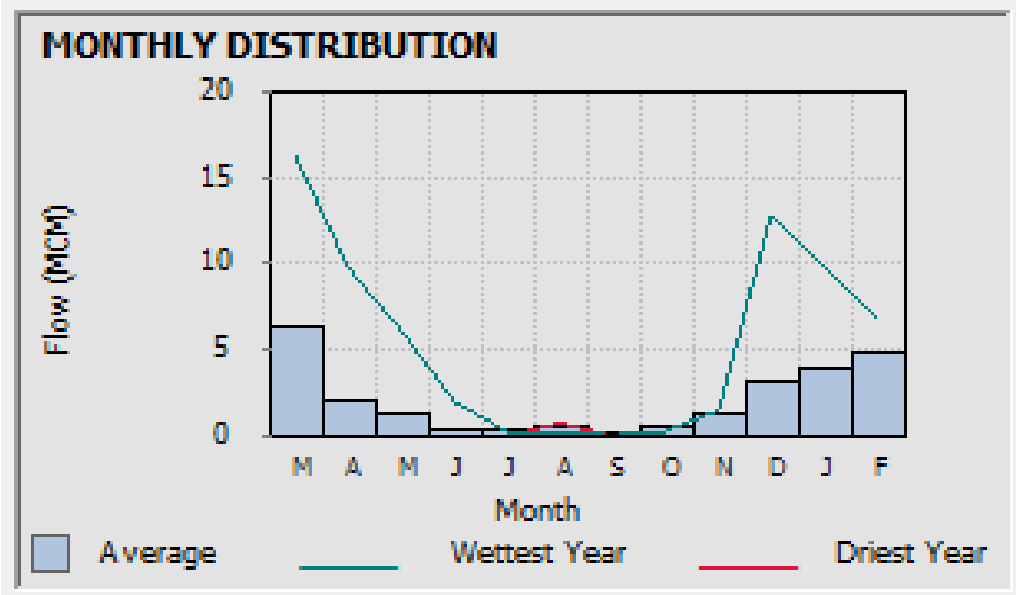

Figure 3-Monthly distribution of the Dalfard River discharge

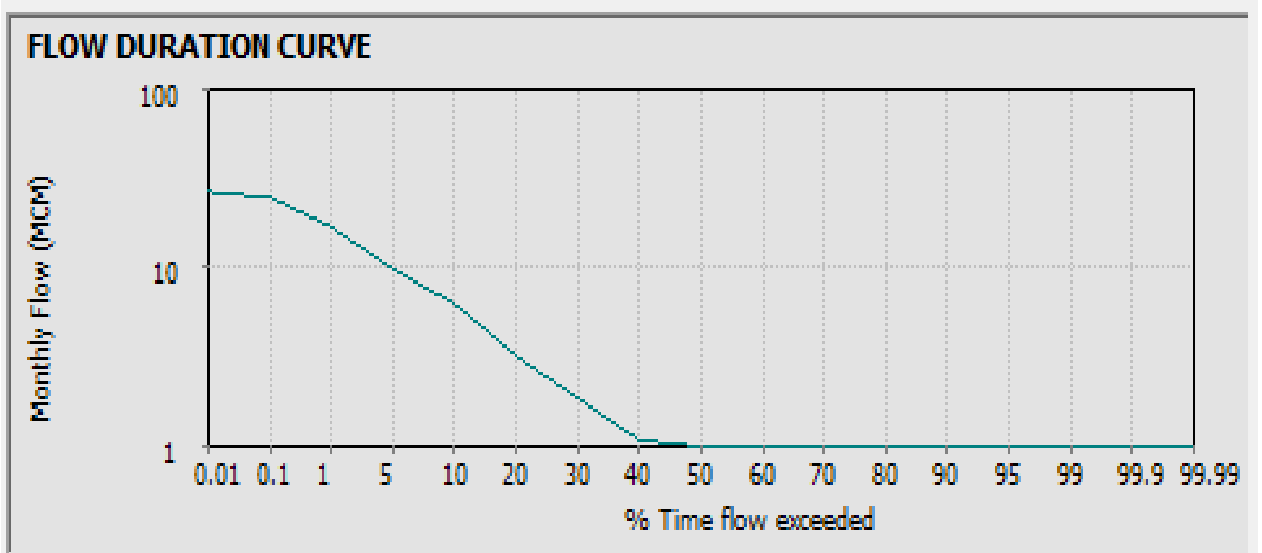

Figure 4-Flow duration curve of the Dalfard River 
Table 3-Average monthly flow of Koldan hydrometric station with statistical period (1987-2018)

\begin{tabular}{cc}
\hline Month & Average flow discharge $\left(\mathrm{m}^{3} \cdot \mathrm{s}^{-1}\right)$ \\
\hline January & 1.16 \\
February & 1.52 \\
March & 1.79 \\
April & 2.37 \\
May & 0.86 \\
June & 0.47 \\
July & 0.16 \\
August & 0.12 \\
September & 0.19 \\
October & 0.10 \\
November & 0.22 \\
December & 0.49 \\
\hline
\end{tabular}

\section{3-2-The results of the average base flow method}

Table 4 shows the environmental discharge obtained from the averaged base flow method. As shown in Table 4, the average base flow method estimates the mean environmental water requirement of the Dalfard River at the Koldan hydrometric station, the value of 0.10 cubic meters per second. Some researchers believe that the averaged base flow method can not be cited Because without considering seasonal variations, the percentage of continuity and probability of occurrence, the lowest monthly discharge that occurs has been set as the minimum environmental discharge (mirakhorli et al, 2012).

Table 4-Environmental discharge obtained from the average base flow (ABF) method

\begin{tabular}{ccc}
\hline Month & Average flow discharge $\left(\mathrm{m}^{3} \mathrm{~s}^{-1}\right)$ & $\begin{array}{c}\text { Estimated environmental water } \\
\text { requirement by ABF method }\end{array}$ \\
\hline January & 1.16 & 0.10 \\
February & 1.52 & 0.10 \\
March & 1.79 & 0.10 \\
April & 2.37 & 0.10 \\
May & 0.86 & 0.10 \\
June & 0.47 & 0.10 \\
July & 0.16 & 0.10 \\
August & 0.12 & 0.10 \\
September & 0.19 & 0.10 \\
October & 0.10 & 0.10 \\
November & 0.22 & 0.10 \\
December & 0.49 & 0.10 \\
\hline
\end{tabular}

\section{3-3-The results of the Tennant method}

Table 5 shows the discharge obtained from the Tennant method for various management levels of the Dalfard River in the Koldan hydrometric station. In the Tennant method, according to the Ministry of Energy's issued instructions, the acceptable level of this method is 30\% of the mean annual flow for April to September, and $10 \%$ of the mean annual flow for October to March. Accordingly, for the Dalfard River at the hydrometric station of Koldan, for the six months of April to September, the amount of $0.24 \mathrm{~m}^{3} \mathrm{~s}^{-1}$ and for the six months of October to March was calculated $0.08 \mathrm{~m}^{3} \mathrm{~s}^{-1}$ as an environmental requirement. 
Table 5-The discharge obtained from the Tennant method for various management levels

\begin{tabular}{ccc}
\hline Flow general situation & $\begin{array}{c}\text { Proposal discharge for spring- } \\
\text { summer }\left(\mathrm{m}^{3} \mathrm{~s}^{-1}\right)\end{array}$ & $\begin{array}{c}\text { Proposal discharge for autumn- } \\
\text { winter }\left(\mathrm{m}^{3} \mathrm{~s}^{-1}\right)\end{array}$ \\
\hline Outstanding & 0.47 & 0.31 \\
Excellent & 0.39 & 0.24 \\
Good & 0.31 & 0.16 \\
Fair or degrading & 0.24 & 0.08 \\
Poor or minimum & 0.08 & 0.08 \\
Severe degradation & $<0.08$ & $<0.08$ \\
\hline
\end{tabular}

Even though Tennant method is best suited for developed countries like USA where the hydrological and ecological characteristics of river are well studied and well understood and region-specific, but in developing countries where adequate data is in scarcity, suitability of the method need to be ascertained. Tenant method is not reliable method for planning purpose. Tenant methods proposes the value of minimum environmental flow and optimum environmental flow as equal to the $10 \%$ and $60-100 \%$ of mean annual flow (MAF) respectively, whereas for outstanding, excellent and good habitat condition it recommend the percentage of environmental flow differs with seasons (Tennant et al., 1976). Also look-up table which initially developed for USA is not utilisable everywhere and need certain medication based on location parameters (Kumar Kawde et al., 2016). In this process, long time is required, thus leading to time constraint in this method (Kumar Kawde et al., 2016). Besides time constraint, Tenant method involves numbers of limitation like region specificity, approximate value, and implicit relationship between hydrological and ecological characteristics of river ecosystem, etc (Kumar Kawde et al., 2016). The EF can be estimated using MMF (mean monthly flow) or MAF (mean annual flow), or mean 10-daily flow series (Kumar Kawde et al., 2016). However, EF estimate based on 10-daily flow series is most suitable approach as it reflect most precise and adequate variability in EF (environmental flow) series vis-à-vis 10-daily flow series (Kumar Kawde et al., 2016). The percentage of EFR (environmental flow runoff) reduces with degradation in habitat condition and flow regulation in riverine ecosystem. EF variability with respect to time decrease with degradation in habitat condition and flow regulation in riverine ecosystem (Kumar Kawde et al., 2016). In this method, the microhabitat and microhabitat condition which implies ecological characteristics of riverine regime is presented by the environmental management class or category (EMC). The major limitation of this method in non-inclusion of intraannual and inter-annual variation in flow series (Kumar Kawde et al., 2016).

\section{3-4-The results of the Tessman method}

The Tessman method is based on the Tennant method and by comparing the available monthly flow with the average annual flow, the minimum environmental water requirement that is essential for the ecosystem of the river recommended for different months. Table 6 presents the environmental flow values calculated by Tessman method. Also, the Tessman method offers a value of 0.37 cubic meters per second (average flow) for the Dalfard River as an environmental requirement.

Table 6-Environmental flow calculated at Koldan station using Tessman method

\begin{tabular}{cccccc}
\hline Month & MMF & 40 \% of MMF & MAF & 40 \% of MAF & Flow proposed by Tessman \\
\hline January & 1.16 & 0.46 & 0.78 & 0.31 & 0.46 \\
February & 1.52 & 0.61 & 0.78 & 0.31 & 0.61 \\
March & 1.79 & 0.71 & 0.78 & 0.31 & 0.71 \\
April & 2.37 & 0.95 & 0.78 & 0.31 & 0.95 \\
May & 0.86 & 0.34 & 0.78 & 0.31 & 0.34 \\
June & 0.47 & 0.18 & 0.78 & 0.31 & 0.31 \\
July & 0.16 & 0.06 & 0.78 & 0.31 & 0.16 \\
August & 0.12 & 0.05 & 0.78 & 0.31 & 0.12 \\
September & 0.19 & 0.08 & 0.78 & 0.31 & 0.19 \\
October & 0.10 & 0.04 & 0.78 & 0.31 & 0.1 \\
November & 0.22 & 0.09 & 0.78 & 0.31 & 0.22 \\
December & 0.49 & 0.2 & 0.78 & 0.31 & 0.31 \\
\hline
\end{tabular}

Tessman method provides more variable EF series than Tennant method. Besides this method removes the spatial restriction problems exhibiting in tenant method and provides more accurate and precise value of EFR (Kumar Kawde et al., 2016). 


\section{3-5-The results of the FDC Shifting method}

To calculate the environmental water requirement, the GEFC software was used for FDC shifting. This method provides different flows for different management classes. The results obtained from the FDC shifting method as a percentage of the mean annual runoff (MAR) in Table 7 and the continuity curve of the environmental flow for the six environmental management classes A to F derived from the model are presented in Figure 5. Table 8 presents the management levels and discharges obtained from the FDC Shifting method for the Koldan hydrometric station located on the Dalfard River. In this research, according to the classification of the river into different environmental management classes, the $\mathrm{C}$ class (maintaining the minimum environmental conditions of the river) was selected as the management class. The monthly flow distribution diagram on the Koldan hydrometric station located on the Dalfard River and estimated values of this method as an environmental discharge in the $\mathrm{C}$ class is presented in Figure 6. The FDC shifting method as a hydrological-ecological combined method presents the environmental requirement based on the ecological viewpoint in different environmental management categories according to the environmental conditions of the river and using hydrometric station monthly flow statistics on the river.

Table 7-Environmental water requirement of the Dalfard River, as a percentage of MAR

\begin{tabular}{ccc}
\hline Mean Annual Runoff $\left(\mathrm{m}^{3} \mathrm{~s}^{-1}\right)$ & Environmental management classes & \% Natural MAR \\
\hline $0.78 \mathrm{~m}^{3} \mathrm{~s}^{-1}$ & A class & $68.8 \%$ \\
& B class & $51.3 \%$ \\
C class & $42.8 \%$ \\
D class & $39.3 \%$ \\
& E class & $38.1 \%$ \\
& F class & $37.9 \%$ \\
\hline
\end{tabular}

Table 8-Management levels and discharges obtained from the FDC Shifting method of the Dalfard River

\begin{tabular}{cc}
\hline Environmental management classes & Discharge $\left(\mathrm{m}^{3} \mathrm{~s}^{-1}\right)$ \\
\hline A class & 0.537 \\
B class & 0.400 \\
C class & 0.334 \\
D class & 0.307 \\
E class & 0.297 \\
F class & 0.295 \\
\hline
\end{tabular}

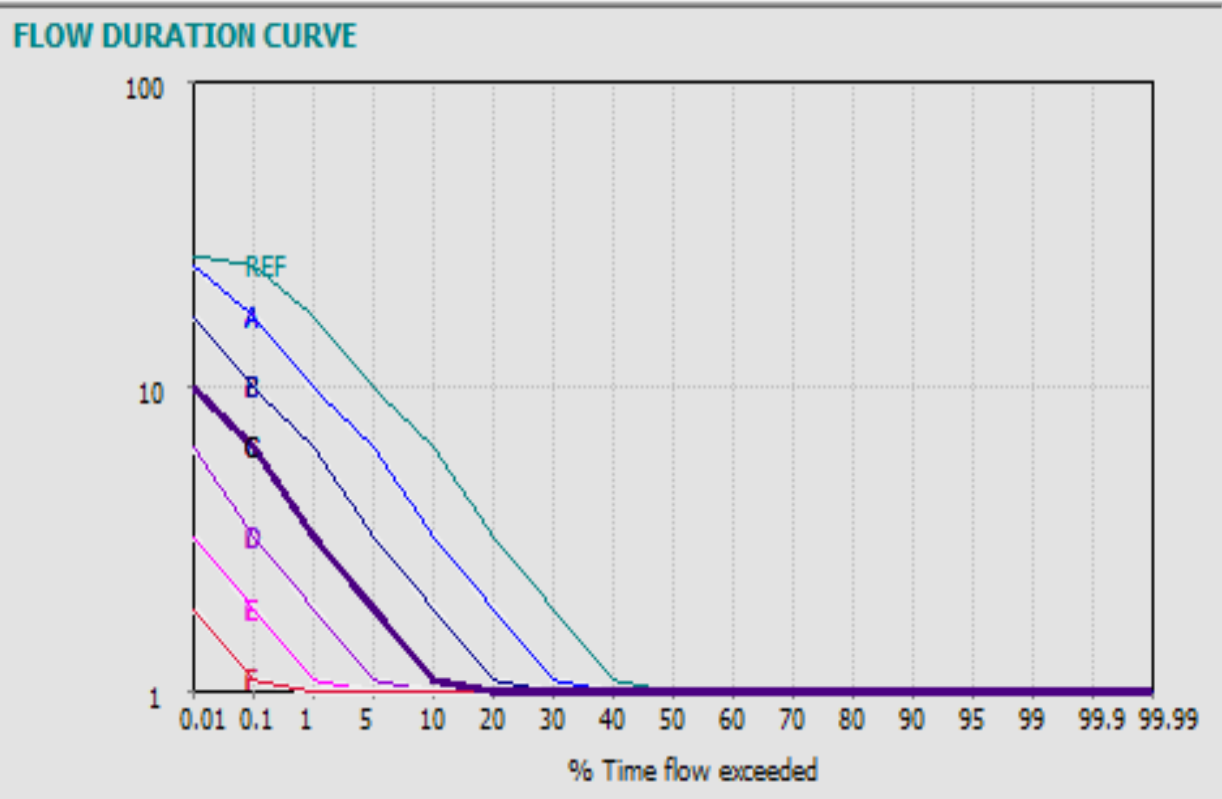

Figure 5-environmental flow duration curve in the Dalfard River 


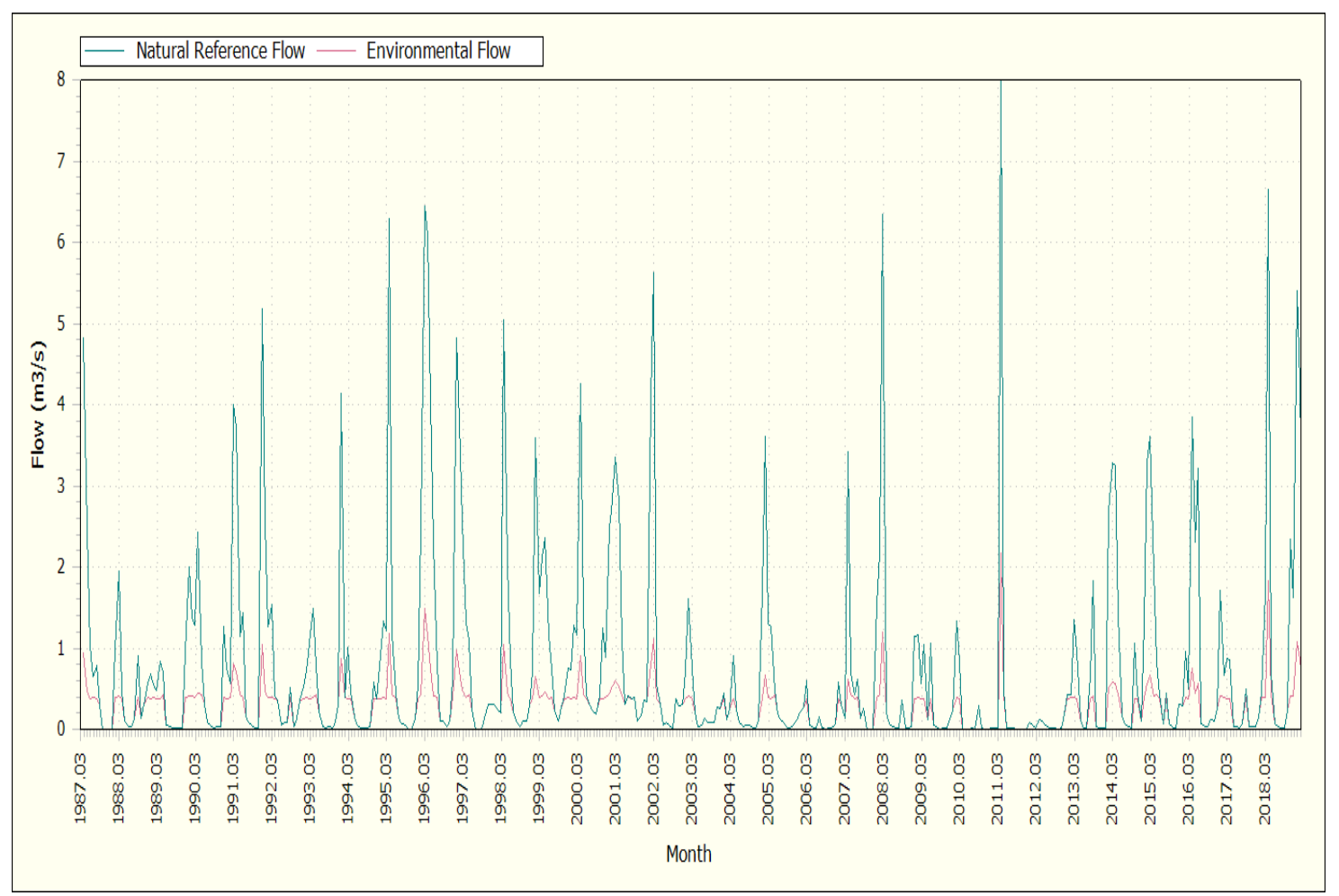

Figure 6-natural and environmental flow monthly distribution chart at the Dalfard River

\section{4-Conclusion}

The calculation of the environmental flow for the river in the present situation is a necessity. Many methods for estimating environmental water requirement is provided. Choosing the best method for a particular river takes place considering the importance, time, finances and available data. The findings of this study show that the Tennant method, considering the $30 \%$ average annual discharge for the spring and summer seasons, and the $10 \%$ average annual discharge for autumn and winter seasons, are 0.24 and 0.08 cubic meters per second, respectively. Average base flow (ABF) and Tessman methods also estimate the environmental water requirement of the Dalfard River 0.10 and 0.37 cubic meters per second, respectively. The calculations performed to estimate the environmental requirement of hydrological methods of Tennant and Tennant are based on hydrological information and the results obtained from these methods do not directly relate to the ecological characteristics of the river system. Many researchers have concluded in their research that taking into account the ecological parameters have a significant impact on the correct and realistic estimation of the environmental requirement. Therefore, it should be kept in mind that the hydrological method alone will not be reliable without taking into account the hydraulic conditions and river ecosystem and finally, we need ecological data for an adequate estimate, and these methods alone do not provide all of the environmental and economic aspects of the water basins. The discharge obtained cannot be reliable from the Average base flow method. Because without considering the seasonal changes, the percentage of continuity and the probability of occurrence; the lowest monthly discharge that has occurred considers as the minimum environmental discharge. Therefore, among the methods studied, the flow duration curve shifting (FDC shifting) method due to the consideration of different ecological classes, attention to the natural variability of the flow and trying to maintain this variability in its proposed environmental flows is preferable to other methods. Since the ecological information needed to determine environmental flows in Iran is still unavailable, the use of GEFC software provides acceptable results. On this basis, we can say that the values obtained from the flow duration curve shifting (FDC shifting) method in class $\mathrm{C}$ of environmental management (Maintain minimum environmental conditions of the river) are proposed due to consideration of the ecological management conditions of the river. So the environmental water requirement in Dalfard River about $0.334 \mathrm{~m}^{3} \mathrm{~s}^{-1}$ equivalent to 42.8 percent of average flow. 


\section{References}

[1] Abdi, R., Yasi, M., Sokooti Oskoui, R. \& Mohamadi, E. (2014). Environmental requirement assessment in Zarrinehrood River by hydrological methods, Watershed Engineering and Management, 6 (3), 211-223.

[2] Behmanesh, J., Mostafavi, S. \& Zamanzad Ghavidel, S. (2017). Use of Soft Calculations at Estimation and Prediction of Environmental Flow Discharge (Case Study: Khorkhoreh Chay River), Journal of Civil and Environmental Engineering, 47(3), 9-22.

[3] DWAF (Department of Water Affairs and Forestry). (1999). Resource Directed Measures for Protection of Water Resources," Volume 8: Classification System for Water Resources, DWAF, Pretoria, South Africa.

[4] Gopal, B. (2013). Environmental flows: An introduction for water resources managers. National Institute of Ecology, New Delhi, 248.

[5] Hughes, D. A., \& Smakhtin, V. (1996). Daily flow time series patching or extension: a spatial interpolation approach based on flow duration curves. Hydrological Sciences Journal, 41(6), 851-871.

[6] Karimi, S. S., Yasi, M., \& Eslamian, S. (2012). Use of hydrological methods for assessment of environmental flow in a river reach. International Journal of Environmental Science and Technology, 9(3), 549-558.

[7] Kumar Kawde, S., Jain, M.K., \& Durbude, D.G. (2016). Environmental flow assessment: A review, Journal of Indian Water Resources Society, 36(3), 1-5.

[8] Maunder, D., \& Hindley, B. (2005). Establishing Environmental Flow Requirements-Synthesis Report. Prepared for Ministry of the Environment, the Department of Fisheries \& Oceans, Credit Valley Conservation and Conservation Ontario.

[9] Mirakhorli, S., saeidi, P., aghashahi, M. \& mehrdadi, N. (23 24 May 2012). Estimating environmental flow of sefidrood river at ghezelozan station, National Conference on Water Flow and Pollution, University of Tehran, Iran.

[10] Mostafavi, S. \& Yasi, M. (2015). Evaluation of Environmental Flows in Rivers Using Hydrological Methods (Case study: The Barandozchi River- Urmia Lake Basin), Journal of Water and Soil, 29 (5), 1219-1231.

[11] Panahi, Gh., Khodashenas, S.R. \& Faridhoseini, A.R. (2017). Evaluation of Methods for Estimating Environmental Flow in Rivers, Journal of Water and Sustainable Development, 4(1), 73-80.

[12] Razzaghi Rezaeieh, A., Ahmadi, H., Haghdoust, N.A. \& Hessari, B. (2019). The evaluation of river environmental flow by using the ecohydrological methods (Case study: Mahabad-Chai River), Water and Soil Conservation, 25(6), 47-65.

[13] Shaeri Karimi, S., Eslamian, S.\& Modarres, R. (May 8-10, 2012). Estimating Environmental Flow for Millhaven Creek, Canada, $9^{\text {th }}$ International Congress on Civil Engineering, Isfahan University of Technology (IUT), Isfahan, Iran.

[14] Shahriari Nia, E., Asadollahfardi, Gh. \& Heydarzadeh, N. (24-26 Feb 2015). Hydrological Assessment of Environmental Flow of Rivers, International conference on sustainable development, strategies and challenges with a focus on Agriculture, Natural Resources, Environment and Tourism, Tabriz, Iran.

[15] Smakhtin, V. U. \& Anputhas, M. (2006). An assessment of environmental flow requirements of Indian river basins, IWMI Research Report 107. International Water Management Institute.

[16] Smakhtin, V. U., \& Eriyagama, N. (2008). Developing a software package for global desktop assessment of environmental flows. Environmental Modelling \& Software, 23(12), 1396-1406.

[17] Tennant, D. L. (1976). Instream flow regimens for fish, wildlife, recreation and related environmental resources. Fisheries, 1(4), 6-10.

[18] Tharme, R. E. (2003). A global perspective on environmental flow assessment: emerging trends in the development and application of

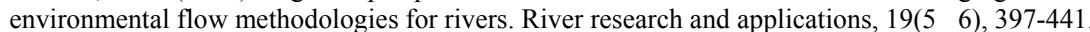

